\title{
Differences in cause and 12-month follow- up outcome of parkinsonian symptoms in depressed older adults treated with antipsychotics: a case series
}

Anastasios Politis ${ }^{1}$, Nikolaos Kokras ${ }^{2}$, Michael Souvatzoglou $^{3}$, Kostas Siarkos $^{4}$, Panagiotis Toulas ${ }^{5}$, Constantin Potagas ${ }^{6}$, Theodoros Hatzipanagiotou ${ }^{7}$, Georgios Limouris ${ }^{3}$ and Panagiotis Alexopoulos ${ }^{8,9^{*}}$ (i)

\begin{abstract}
Background: Parkinsonian symptoms are common adverse effects of antipsychotics. Older adults are particularly vulnerable to drug-induced parkinsonism. Nonetheless, parkinsonian symptoms in seniors treated with antipsychotics cannot be straightforwardly attributed to antipsychotic medication. A comprehensive diagnostic workup is necessary in many cases in order to shed light on the cause of such symptoms in this patient population.

Case series: Eight cases of hospitalized depressed older adults with parkinsonian symptoms, who were treated for at least one year with antipsychotics, are reported. Based on neurological consultation, structural brain imaging and loflupane (I-123) dopamine transporter (DAT) single photon emission computerized tomography (SPECT),

Parkinson's disease was diagnosed in one case, idiopathic tremor in another, vascular parkinsonism in another one, while in another individual parkinsonian symptoms persisted at 12-month post-discharge follow-up even though his/her symptoms were classified as drug-induced on discharge. In four patients, parkinsonian symptoms were definitely drug-induced and no movement disturbances were reported at follow-up.

Conclusions: Differences in the cause and outcome of parkinsonian symptoms in seniors treated with antipsychotics merit systematic and in-depth study considering the therapeutic and prognostic implications of an accurate detection of the cause of such symptoms. Familiarizing clinical psychiatrists with these differences could pave the way towards approaching seniors with severe, atypical and/or persistent parkinsonian symptoms in a more individualized diagnostic and therapeutic manner, and towards more cautious prescribing of antipsychotics in this age group.
\end{abstract}

Keywords: Drug induced parkinsonism, Parkinson's disease, Vascular parkinsonism, Idiopathic tremor, Case series

\footnotetext{
*Correspondence: panos.alexopoulos@upatras.gr

${ }^{8}$ Department of Psychiatry, Patras University Hospital, Faculty of Medicine, School of Health Sciences, University of Patras, 26504 Rion, Patras, Greece ${ }^{9}$ Department of Psychiatry and Psychotherapy, Klinikum rechts der Isar, Faculty of Medicine, Technical University of Munich, Munich, Germany Full list of author information is available at the end of the article
} 


\section{Background}

Antipsychotic augmentation is not a rare strategy in the pharmacological treatment of depression in older adults. The prevalence of clinically relevant depressive symptoms in seniors is higher than $15 \%$, while the prevalence of major depression exceeds 5\% [1, 2]. Antipsychotics augment antidepressants in $12-32 \%$ of older adults with depression [3-6], albeit in most cases in an off-label manner [7]. Antipsychotics contribute not only to treating psychotic symptoms in severe depression with psychotic features [8], but also to depressive symptom improvement, since they enhance monoaminergic neurotransmission [9].

Seniors are particularly vulnerable to side effects of antipsychotic agents, such as parkinsonian symptoms. Both typical antipsychotics, which mainly block D2 receptors, and to a lesser degree atypical ones, blocking both D2 and serotonin 5-HT2A receptors, can lead to parkinsonian symptoms $[10,11]$. The annual prevalence of drug-induced parkinsonian symptoms approximates $3 \%$ and the annual incidence rate is higher than 3 per 100,00 person-years [12, 13]. Seniors are more vulnerable to parkinsonian symptoms compared to younger patients due to age- related changes in the brain's response to antipsychotics, diminished drug metabolizing capacity, alterations in blood-brain barrier, as well as drug-drug interactions in an age group burdened by polypharmacy [14]. In addition, age- related, still presymptomatic, neurodegenerative (e.g. Lewy-bodies, nigral cell degeneration) $[12,15]$ and/or vascular brain changes [16] should be considered as factors crucially implicated in the high susceptibility of seniors treated with antipsychotics to develop severe and persistent parkinsonian symptoms which cannot be unambiguously classified into diagnostic categories. Structural imaging and Ioflupane (I123) dopamine transporter (DAT) single photon emission computerized tomography (DaTSAN) are useful tools in shedding light on such brain changes and assisting the differential diagnosis [17, 18]. Normal DaTSCAN-imaging supports diagnosis of a condition not involving nigrostriatal neurodegeneration such as Alzheimer's disease, essential tremor or drug-induced parkinsonism and hence a different therapeutic approach [19]. DaTSCAN sensitivity is estimated to be $78-100 \%$ and specificity $70-100 \%$ for differentiating neurodegenerative versus non-neurodegenerative parkinsonism [20].

Here, we report on eight hospitalized depressed older adults with parkinsonian symptoms who were treated for at least 12 months prior to their hospital admission with antipsychotics. The presented case series highlights the different causes and 12-month post-discharge follow-up outcomes of such symptoms, despite the initial assessment on admission that they were druginduced.

\section{Case series presentation}

The case series consists of five women and three men older than 59 years who were admitted between 2012 and 2017 to the old age psychiatry division of the Eginition Hospital in Athens because of severe depressive symptoms and consecutively agreed to undergo brain SPECT with 123I-FP-CIT (DaTSCAN, GE Healthcare). The brief, focused neurological examination on admission revealed parkinsonian symptoms, which had been developed during exposure to antipsychotic treatment (Table 1). On admission, each patient was on antipsychotic medication that had not been changed in the twelve months prior to his/her hospital admission (Table 1). Five patients were on atypical and three on typical antipsychotics; four were on serotonin and norepinephrine reuptake inhibitors, two on selective serotonin reuptake inhibitor and four were treated with mirtazapine. Except for one patient, who had received the diagnosis of bipolar disorder many years before current hospital admission, all others had been diagnosed with unipolar depression. Of note, depression had occurred among four patients for the first time at an age greater than or equal to 65 years with no previous history of depression.

The diagnostic workup of depressive symptoms included a history from the patient and from an informant; psychiatric examination; laboratory screening and the administration of the 30-point Mini-Mental State Examination (MMSE) [21] and the Geriatric depression scale15 [22]. Geriatric depression scale score was in all cases higher than 11, highlighting the severity of depressive symptoms (Table 1). In four patients MMSE score was lower than 24 points, pointing to major neurocognitive disorder [21], even though the magnitude of the detected cognitive deficits was supposed to be at least partially potentiated by the depressive syndrome [23].

Patients were diagnosed with antipsychotic- induced parkinsonism according to the International Statistical Classification of Diseases and Related Health Problems version 10 (ICD-10) diagnostic criteria [24]. Severity of parkinsonian symptoms was graded with the SimpsonAngus scale (SAS), being an established instrument of neuroleptic-induced parkinsonism [25]. The instrument is a 10-item rating scale that measures gait (hypokinesia) with one item, rigidity with six items, whilst three additional items assess glabella tap, tremor and salivation, respectively. Items are rated from 0 to 4 points, yielding a total body score divided by 10 , and considered normal up to 0.3. It was performed in all cases by the same psychiatrist (KS). Apart from one case, in all other patients total scores on SAS exceeded 0.5 (Table 2). 
Table 1 Demographic and clinical data, mental disorder history and medication of older adults with depression and parkinsonian symptoms on hospital admission

\begin{tabular}{|c|c|c|c|c|c|c|c|c|c|}
\hline \multirow[t]{2}{*}{$\begin{array}{l}\text { Case } \\
\text { No }\end{array}$} & \multirow[t]{2}{*}{$\begin{array}{l}\text { Age } \\
\text { range }\end{array}$} & \multirow[t]{2}{*}{$\begin{array}{l}\text { Education } \\
\text { (in years) }\end{array}$} & \multicolumn{2}{|c|}{$\begin{array}{l}\text { Neuropsychological } \\
\text { assessment at admission }\end{array}$} & \multirow{2}{*}{$\begin{array}{l}\text { Duration } \\
\text { of current } \\
\text { depressive } \\
\text { syndrome } \\
\text { (in years) }\end{array}$} & \multirow{2}{*}{$\begin{array}{l}\text { Past mental } \\
\text { disorder } \\
\text { diagnoses }\end{array}$} & \multirow{2}{*}{$\begin{array}{l}\text { Age of } \\
\text { onset of } \\
\text { the first } \\
\text { mental } \\
\text { disorder } \\
\text { episode }\end{array}$} & \multirow[t]{2}{*}{$\begin{array}{l}\text { Medication on admission } \\
\text { (in mg/day) }\end{array}$} & \multirow[t]{2}{*}{ Comorbidities } \\
\hline & & & $\begin{array}{l}\text { Geriatric } \\
\text { depression } \\
\text { scale score }\end{array}$ & $\begin{array}{l}\text { Mini mental } \\
\text { state } \\
\text { examination } \\
\text { score }\end{array}$ & & & & & \\
\hline 1 & $71-85$ & 12 & 12 & 21 & 1 & $\begin{array}{l}\text { Major } \\
\text { depression }\end{array}$ & 69 & $\begin{array}{l}\text { Amisulpiride (100), } \\
\text { venlafaxine ( } 75) \text {, mirtazapine } \\
\text { (30), ferrous sulfate, } \\
\text { nifedipine (40) }\end{array}$ & $\begin{array}{l}\text { Anaemia, } \\
\text { hypertension }\end{array}$ \\
\hline 2 & $71-85$ & 14 & 14 & 27 & 1 & $\begin{array}{l}\text { Severe } \\
\text { depressive } \\
\text { episode with } \\
\text { psychotic } \\
\text { symptoms }\end{array}$ & 72 & $\begin{array}{l}\text { Risperidone (3), sertraline } \\
\text { (200 mg), mirtazapine (30), } \\
\text { lorazepam (2.5), irbesartan } \\
\text { (150), metoprolol (100) }\end{array}$ & $\begin{array}{l}\text { Hypertension, } \\
\text { hypothyreroidism }\end{array}$ \\
\hline 3 & $56-70$ & 14 & 14 & 28 & 1 & $\begin{array}{l}\text { Severe } \\
\text { depressive } \\
\text { episode with } \\
\text { psychotic } \\
\text { symptoms }\end{array}$ & 57 & $\begin{array}{l}\text { Olanzapine (5), mirtazapine } \\
\text { (45), alprazolam (3), } \\
\text { flunitrazepam (1), biperiden } \\
\text { (4) }\end{array}$ & None \\
\hline 4 & $56-70$ & 14 & 15 & 20 & 1 & $\begin{array}{l}\text { Moderate to } \\
\text { severe } \\
\text { depressive } \\
\text { episode }\end{array}$ & 36 & $\begin{array}{l}\text { Haloperidol (10), venlafaxine } \\
\text { (150), lorazepam ( } 7.5), \\
\text { biperiden (6), pindolol (5), } \\
\text { rosuvastatin (10), } \\
\text { atorvastatin (10) }\end{array}$ & $\begin{array}{l}\text { Hypertension, } \\
\text { dislipidemia }\end{array}$ \\
\hline 5 & $71-85$ & 8 & 12 & 27 & 1 & $\begin{array}{l}\text { Moderate to } \\
\text { severe } \\
\text { depressive } \\
\text { episode with } \\
\text { psychotic } \\
\text { symptoms }\end{array}$ & 77 & $\begin{array}{l}\text { Haloperidol (10), sertraline } \\
\text { (100), bromazepam ( } 3 \text { ), } \\
\text { amiloride hydrochloride/ } \\
\text { hydrochlorothiazide (5/50) }\end{array}$ & Hypertension \\
\hline 6 & $71-85$ & 12 & 14 & 23 & 1 & $\begin{array}{l}\text { Bipolar } \\
\text { disorder }\end{array}$ & 54 & $\begin{array}{l}\text { Risperidone (3), mirtazapine } \\
(45) \text {, gabapentin (600), } \\
\text { clonazepam (2), baclofen } \\
\text { (20), metformin (2000), } \\
\text { rosuvastin (20), bisoprolol } \\
\text { fumarate (5), Levothyroxine } \\
\text { sodium (125 } \mu \mathrm{g} \text { ) }\end{array}$ & $\begin{array}{l}\text { Hypertension, } \\
\text { diabetes mellitus, } \\
\text { coronary heart } \\
\text { disease, } \\
\text { dyslipidemia, } \\
\text { hypothyroidism }\end{array}$ \\
\hline 7 & $71-85$ & 6 & 15 & 27 & 1 & $\begin{array}{l}\text { Severe } \\
\text { depressive } \\
\text { episode with } \\
\text { psychotic } \\
\text { symptoms }\end{array}$ & 76 & $\begin{array}{l}\text { Haloperidol (20), venlafaxine } \\
\text { (150), pramipexol (0.18), } \\
\text { quinapril (20), rabeprazole } \\
\text { (10) }\end{array}$ & Hypertension \\
\hline 8 & $56-70$ & 12 & 13 & 19 & 1 & $\begin{array}{l}\text { Moderate to } \\
\text { severe } \\
\text { depressive } \\
\text { episodes }\end{array}$ & 55 & $\begin{array}{l}\text { Quetiapine (100), duloxetine } \\
\text { (30), pregabalin ( } 75) \text {, } \\
\text { levodopa/benserazide (200/ } \\
\text { 50) }\end{array}$ & Hypertension \\
\hline
\end{tabular}

Brain MRI (3 T) was performed during the hospitalization period. It included $\mathrm{T} 1$ weighted sequences on coronal, sagittal and axial planes (or isotropic T1 images), T2 weighted sequences, T2 Fluid Attenuation Inversion Recovery (FLAIR) images and Diffusion Weighted Imaging (DWI). All MRI scans were evaluated by an experienced neuroradiologist (PT). White matter lesions and vascular disease were evaluated using the Fazekas scale on T2-FLAIR sequences [26]. This scale ranges from 0 (no white matter lesions) to 3 (large confluent areas of white matter lesions) [27]. Based on the Medial Temporal Lobe Atrophy (MTA) -Scheltens Score, MTA was classified using a scale from 0 (no atrophy) to 4 (maximum atrophy) [28]. Unfortunately, MRI imaging was not conducted in two cases due to MRI contraindications (Table 3). 
Table 2 Parkinsonian symptoms of depressed older adults

\begin{tabular}{|c|c|c|c|c|c|c|c|c|c|c|c|c|}
\hline \multirow{2}{*}{$\begin{array}{l}\text { Case } \\
\text { No }\end{array}$} & \multirow{2}{*}{$\begin{array}{l}\text { Detected } \\
\text { movement } \\
\text { disturbances on } \\
\text { admission }\end{array}$} & \multicolumn{11}{|c|}{ Simpson-Angus Scale } \\
\hline & & $\begin{array}{l}\text { Total } \\
\text { score }\end{array}$ & Gait & $\begin{array}{l}\text { Arm } \\
\text { dropping }\end{array}$ & $\begin{array}{l}\text { Shoulder } \\
\text { shaking }\end{array}$ & $\begin{array}{l}\text { Elbow } \\
\text { rigidity }\end{array}$ & $\begin{array}{l}\text { Wrist } \\
\text { rigidity }\end{array}$ & $\begin{array}{l}\text { Leg } \\
\text { pendulousness }\end{array}$ & $\begin{array}{l}\text { Head } \\
\text { dropping }\end{array}$ & $\begin{array}{l}\text { Glabella } \\
\text { tap }\end{array}$ & Tremor & Salivation \\
\hline 1 & Parkinsonism & 0.7 & 1 & 1 & 0 & 1 & 2 & 0 & 1 & 0 & 1 & 0 \\
\hline 2 & Parkinsonism & 0.9 & 2 & 1 & 0 & 0 & 2 & 1 & 0 & 1 & 2 & 0 \\
\hline 3 & Parkinsonism & 0.6 & 1 & 1 & 1 & 0 & 1 & 1 & 0 & 0 & 1 & 0 \\
\hline 4 & Parkinsonism & 1.4 & 1 & 1 & 1 & 1 & 2 & 1 & 1 & 1 & 3 & 1 \\
\hline 5 & Parkinsonism & 1.6 & 2 & 2 & 2 & 2 & 1 & 2 & 1 & 1 & 3 & 0 \\
\hline 6 & Parkinsonism & 1.3 & 2 & 2 & 1 & 2 & 2 & 1 & 1 & 1 & 1 & 0 \\
\hline 7 & Parkinsonism & 0.3 & 0 & 1 & 0 & 0 & 1 & 0 & 0 & 0 & 1 & 0 \\
\hline 8 & Parkinsonism & 1.1 & 1 & 1 & 1 & 1 & 2 & 1 & 1 & 1 & 2 & 0 \\
\hline
\end{tabular}

Slightly increased signal in T2-weighted images in white matter was observed in four cases and beginning confluent lesions were detected in one case, while in case 8 basal ganglia ischemic lesions were bilaterally observed in addition to large confluent white matter lesions (Fig. 1). Mild or moderate MTA was detected in all cases with available MRI data (Table 3).

Due to the severity and persistence of parkinsonian symptoms, despite cessation of antipsychotic medication in four cases or switching to other antipsychotic agents in the rest of cases, the assessment of the basal ganglia's presynaptic dopamine function was recommended. Patients agreed and underwent DaTSCAN. DaTSCAN scintigraphy acquisition and processing methodology as well as the analysis method of the striatal uptake ratios of DaTSCAN images have been previously depicted in detail $[29,30]$. Visual analysis of the data was performed by two nuclear medicine specialists who were blind to patients' clinical status. Tracer uptake patterns were classified according to the Benamer's criteria [31] as normal (preserved and largely symmetrical striatal tracer uptake), or abnormal grade 1 in case of asymmetric uptake with normal or almost normal putamen activity in one hemisphere, and with a more marked reduction in the contralateral putamen, or abnormal grade 2, if significant bilateral reduction in putamen uptake with activity confined to the caudate nuclei was detected, or abnormal grade 3 in cases with virtually absent uptake bilaterally affecting both putamen and caudate nuclei [32]. The semi-quantitative analysis and calculation (cnts/pixel) of striatal uptake was based on manually drawn, irregular (almost ellipsoid) regions of interest (ROIs), encompassing the entire corpus striatum, and square ROIs in areas corresponding to the occipital

Table 3 Brain imaging findings of older adults with depression and parkinsonian symptoms

\begin{tabular}{|c|c|c|c|c|c|c|}
\hline \multirow[t]{3}{*}{ Case No } & \multicolumn{2}{|c|}{ Structural brain MR imaging } & \multicolumn{4}{|c|}{ DaT scan* } \\
\hline & \multirow[t]{2}{*}{ MTA-Scheltens Score ${ }^{* *}$} & \multirow[t]{2}{*}{ White matter lesions/Fazekas Score ${ }^{* * *}$} & \multicolumn{2}{|c|}{ Specific Binding Index right } & \multicolumn{2}{|c|}{ Benamer's criteria ${ }^{* * * *}$} \\
\hline & & & Right & Left & Rater 1 & Rater 2 \\
\hline 1 & 2 & 1 & 2.17 & 2.10 & 0 & 0 \\
\hline 2 & 1 & 2 & 2.05 & 2.12 & 1 & 1 \\
\hline 3 & 1 & 0 & 2.04 & 2.03 & 0 & 0 \\
\hline 4 & \multicolumn{2}{|c|}{ No atrophy / Computerized tomography (CT) scan } & 2.03 & 2.02 & 0 & 1 \\
\hline 5 & 2 & 1 & 2.02 & 2.06 & 0 & 0 \\
\hline 6 & \multicolumn{2}{|c|}{ No atrophy / Computerized tomography (CT) scan } & 2.00 & 1.88 & 2 & 3 \\
\hline 7 & 2 & 1 & 1.85 & 2.07 & 1 & 1 \\
\hline 8 & 2 & Bilateral basal ganglia ischemic lesions/3 & 1.51 & 1.67 & 1 & 1 \\
\hline
\end{tabular}

* iofluropane iodine-123 (DAT) single-photon emission computed tomography imaging (SPECT)

** Medial Temporal Lobe Atrophy (MTA) -Scheltens Score ranging from 0 (no atrophy) to 4 (severe atrophy)

***The 4-point Fazekas score is a whole brain scale: 0: No lesion or a single punctuate white matter lesion; 1: multiple punctuate lesions; 2 : Beginning confluent lesions; 3: large confluent lesions

**** Benamer's criteria: 0: preserved and largely symmetrical striatal tracer uptake; 1 : asymmetric uptake with normal or almost normal putamen activity in one hemisphere, and with a more marked reduction in the contralateral putamen; 2: significant bilateral reduction in putamen uptake with activity confined to the caudate nuclei; 3 : virtually absent uptake bilaterally affecting both putamen and caudate nuclei 


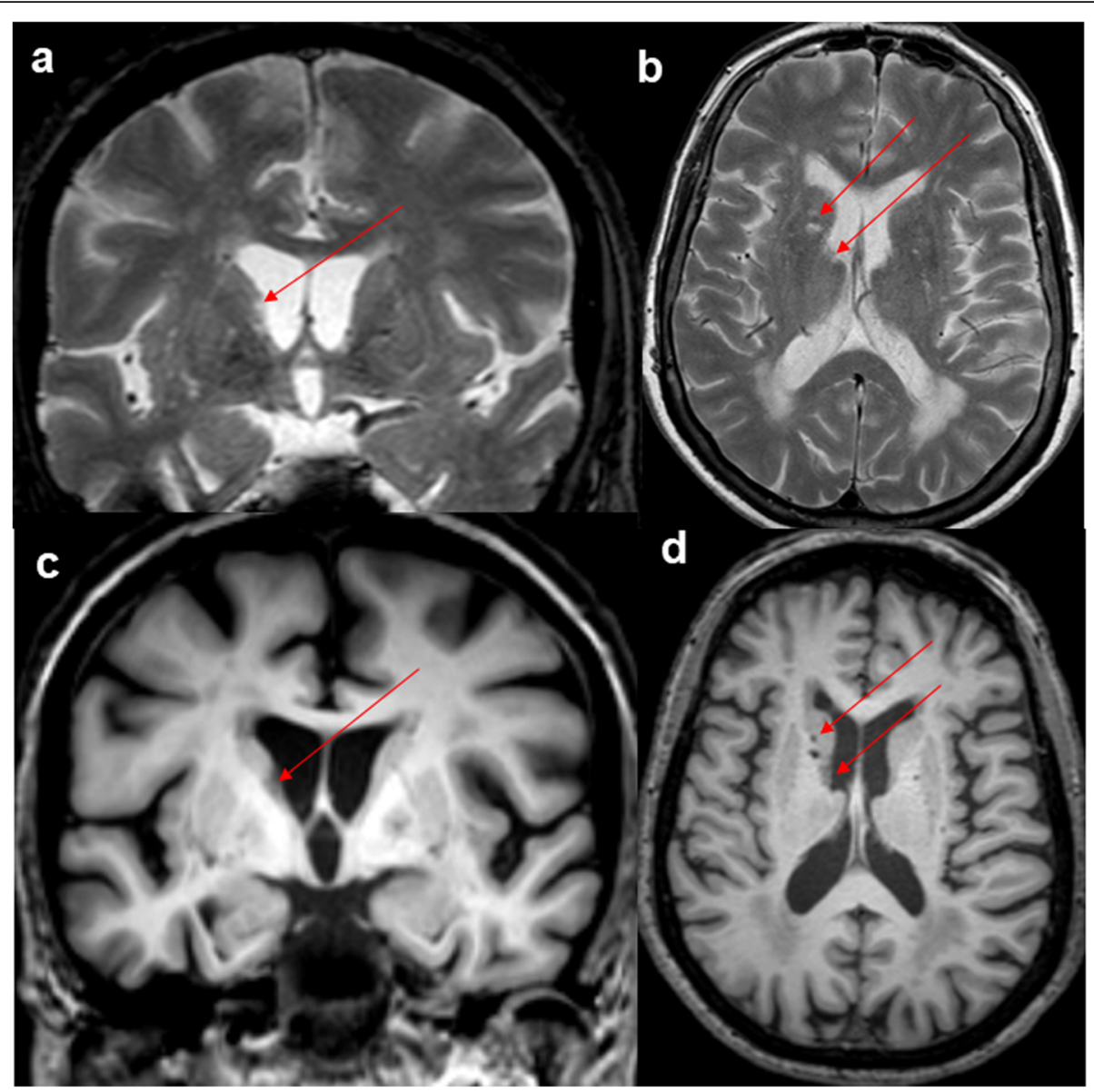

Fig. 1 Brain MRI (3 T) of case 8. Lacunar lesions in superior-anterior-medial surface of right thalamus in the proximity inferior surface of caudal nucleus (arrows) (A: coronal T2* weighted image and B: axial T2 weighted image). Microvascular leukoencephalopathy (Fazekas grade 3). No hemosiderin accumulation in basal ganglia in T2* weighted images. No medial temporal lobe atrophy (C and $\mathbf{D}$ : coronal and axial T1 weighted images)

cortex in the three consecutive 'best' subsets of a transaxial slice through the central striatum of the DaTSCAN image. The specific radiotracer binding ratios of the striatum were calculated from its mean counts per pixel vs those of the occipital cortex as reference [specific binding index in the striatum (S.B.I. $\geq 2.0$ )] $=$ value for the striatum divided to the value for the occipital cortex reference [29]. According to the visual analysis three patients had a normal study; one had a marginally asymmetrical tracer uptake; three patients had an abnormal

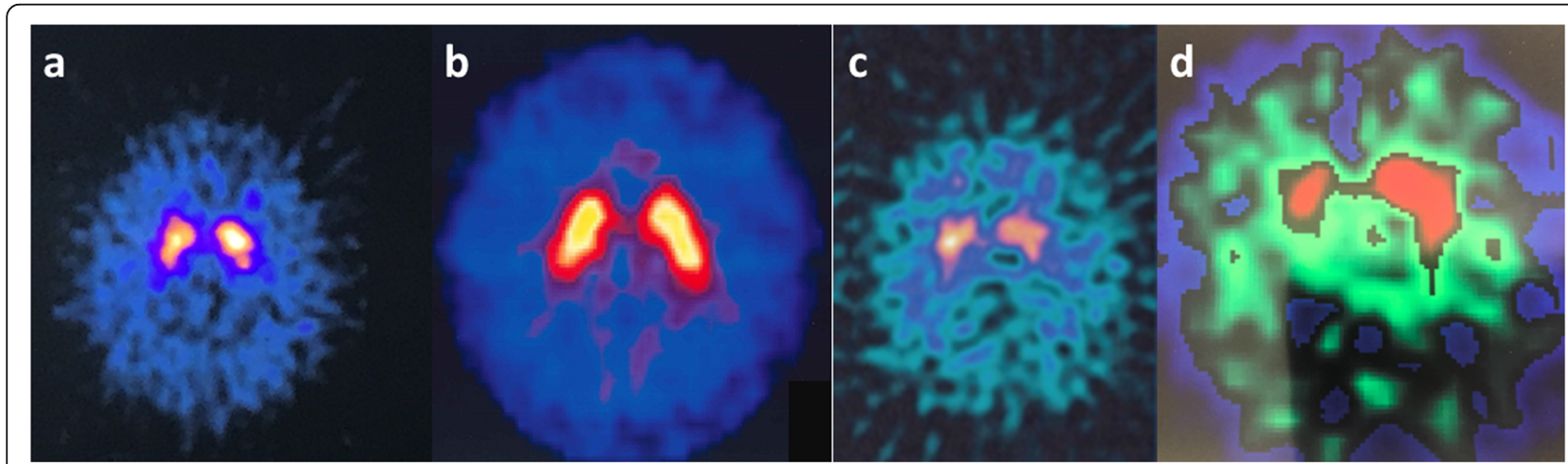

Fig. $2^{123}$-loflupane SPECT imaging, a measure of dopamine transporter density, demonstrates in case 2 normal radiotracer uptake or very mild hypoactivity in right caudate (A); in case 3 normal radiotracer uptake bilaterally (B); in case 6 bilateral striatal hypoactivity $(\mathbf{C})$ and in case 8 bilateral hypoactivity with a more marked reduction in right striatum(D) 
tracer uptake with moderately asymmetric dopaminergic loss and one patient exhibited a significant bilateral reduction in tracer uptake. Consistent with previous reports, the clinical agreement between the two raters was $75 \%[33,34]$. The specific radiotracer binding indexes point to one case with symmetrically abnormal radiotracer uptake and to two cases with unilateral abnormal uptake, whilst in all other patients the uptake was within the normal range (Table 3) (Fig. 2). For the sake of clarity of presentation, the eight cases are presented in all tables in a descending order regarding the semiquantitative calculation of tracer uptake in right striatum.

Based on clinical data, GDS- and MMSE results and imaging findings and in accordance with ICD-10 diagnostic criteria mental disorder- and neurological diagnoses were established [24]. Depressive syndromes were classified as organic mood disorder in four cases and as severe depressive episode of recurrent depressive disorder in the other four. Based on neurological consultation, the diagnosis of Parkinson's disease was established only in one case, whilst one patient with normal striatal tracer uptake was diagnosed with idiopathic tremor and case 8 with vascular parkinsonism. In all other cases parkinsonian symptoms were attributed to the administration of antipsychotics. Mild cognitive impairment due to Alzheimer's disease was diagnosed in two cases. On discharge, no patient was treated with typical antipsychotics, while in four cases no antipsychotics were administered at all. Antiparkinsonian drugs were initiated during hospitalization or continued in six patients (Table 4). Interestingly, apart from one case, the number of prescribed drugs on discharge was lower in five cases or in two cases equal to that of agents with which patients were treated on admission.

For the 12-month post-discharge follow-up outcome assessment, a caregiver-based telephone interview format was employed. The interview was based on questions about movement disturbances and mental disorder- and neurological diagnoses. The individuals diagnosed on discharge with Parkinson's disease, idiopathic tremor and vascular parkinsonism, respectively,

Table 4 Neurological and mental disorder diagnoses and medication on discharge and 12-month post-discharge follow-up outcome regarding movement disturbances and mental disorder- and neurological diagnoses

\begin{tabular}{|c|c|c|c|c|c|}
\hline $\begin{array}{l}\text { Case } \\
\text { No }\end{array}$ & $\begin{array}{l}\text { Hospitalization } \\
\text { duration (in } \\
\text { days) }\end{array}$ & $\begin{array}{l}\text { Discharge neurological } \\
\text { diagnosis }\end{array}$ & $\begin{array}{l}\text { Discharge mental } \\
\text { disorder diagnosis }\end{array}$ & Medication at discharge & $\begin{array}{l}\text { 12-month post- } \\
\text { discharge follow-up } \\
\text { outcome }\end{array}$ \\
\hline 1 & 45 & $\begin{array}{l}\text { Drug-induced } \\
\text { parkinsonism } \\
\text { Mild Cognitive } \\
\text { Impairment due to } \\
\text { Alzheimer's disease }\end{array}$ & Organic mood disorder & Duloxetine (90), donepezil (5) & $\begin{array}{l}\text { No movement } \\
\text { disturbances } \\
\text { Dementia due to } \\
\text { Alzheimer's disease }\end{array}$ \\
\hline 2 & 40 & Idiopathic tremor & $\begin{array}{l}\text { Severe depressive episode } \\
\text { of recurrent depressive } \\
\text { disorder }\end{array}$ & $\begin{array}{l}\text { Quetapine (25), duloxetine }(60) \text {, } \\
\text { clonazepam (2), } \\
\text { levothyroxine sodium }(100 \mu \mathrm{g})\end{array}$ & Idiopathic tremor \\
\hline 3 & 90 & $\begin{array}{l}\text { Drug-induced } \\
\text { parkinsonism }\end{array}$ & $\begin{array}{l}\text { Severe depressive episode } \\
\text { of recurrent depressive } \\
\text { disorder }\end{array}$ & $\begin{array}{l}\text { Risperidone (4), } \\
\text { paroxetine (20), mirtazapine (60), } \\
\text { alprazolam (4), biperiden (4) }\end{array}$ & $\begin{array}{l}\text { No movement } \\
\text { disturbances }\end{array}$ \\
\hline 4 & 120 & $\begin{array}{l}\text { Drug-induced } \\
\text { parkinsonism } \\
\text { Tardive dyskinesia } \\
\text { Mild Cognitive } \\
\text { Impairment due to } \\
\text { Alzheimer's disease }\end{array}$ & $\begin{array}{l}\text { Severe depressive episode } \\
\text { of recurrent depressive } \\
\text { disorder }\end{array}$ & $\begin{array}{l}\text { Quetiapine (150), trazodone (50), } \\
\text { mirtazapine (45), lorazepam (7.5), } \\
\text { biperiden (2), pindolol (5) }\end{array}$ & $\begin{array}{l}\text { Tardive dyskinesia } \\
\text { Dementia due to } \\
\text { Alzheimer's disease }\end{array}$ \\
\hline 5 & 60 & $\begin{array}{l}\text { Drug-induced } \\
\text { parkinsonism }\end{array}$ & Organic mood disorder & $\begin{array}{l}\text { Quetiapine (50), duloxetine (90), lorazepam } \\
(0.5), \\
\text { levodopa/benserazide (100/25), } \\
\text { amiloride, hydrochloride/ } \\
\text { hydrochlorothiazide }(5 / 50)\end{array}$ & $\begin{array}{l}\text { Parkinsonism } \\
\text { Persistent psychotic } \\
\text { symptoms }\end{array}$ \\
\hline 6 & 35 & Parkinson's disease & Organic mood disorder & $\begin{array}{l}\text { Escitalopram (40), lorazepam (1), } \\
\text { levodopa/benserazide (600/150), } \\
\text { amantadine (100) }\end{array}$ & Parkinsonism \\
\hline 7 & 100 & $\begin{array}{l}\text { Drug-induced } \\
\text { parkinsonism }\end{array}$ & $\begin{array}{l}\text { Severe depressive episode } \\
\text { of recurrent depressive } \\
\text { disorder }\end{array}$ & $\begin{array}{l}\text { Duloxetine (60), } \\
\text { mirtazapine (45), } \\
\text { lorazepam (1), } \\
\text { levodopa/benserazide (200/50) }\end{array}$ & $\begin{array}{l}\text { No movement } \\
\text { disturbances } \\
\text { Dementia due to } \\
\text { Alzheimer's disease }\end{array}$ \\
\hline 8 & 40 & $\begin{array}{l}\text { Vascular parkinsonism } \\
\text { Microvascular ischemic } \\
\text { brain disease }\end{array}$ & Organic mood disorder & $\begin{array}{l}\text { Duloxetine (30), rivastigmine (4.6), } \\
\text { levodopa/benserazide (200/50), ilbesartan } \\
\text { (150) }\end{array}$ & $\begin{array}{l}\text { Parkinsonism } \\
\text { Vascular dementia }\end{array}$ \\
\hline
\end{tabular}


still suffered from movement disturbances, as expected. In a patient who had been diagnosed on discharge with drug-induced parkinsonism, persistent movement disturbances were reported, despite the discontinuation of antipsychotic agents during hospitalization. In all other patients no parkinsonian symptoms were reported, in line with the discharge diagnosis of drug- induced parkinsonism. The two patients who received on discharge the diagnosis of mild cognitive impairment due to Alzheimer's disease progressed to dementia and faced at follow-up difficulties with both complex and basic activities of daily living.

\section{Discussion and conclusions}

The development of parkinsonian symptoms while being on antipsychotic medication does not straightforwardly substantiate the presence of drug-induced parkinsonism, especially in seniors. The presented case series, which in contrast to the heterogeneity of study samples of most past reports [35-37], focuses exclusively on older adults with depression treated with antidepressants and antipsychotics, clearly points to a diagnostic riddle in this patient population.

Treatment with antipsychotics can induce parkinsonian symptoms, uncover subclinical degenerative and/or vascular striatal brain pathologies, or lead to the exacerbation of previously mildly manifest parkinsonian symptoms [38]. Drug-induced parkinsonism is conceptualized as parkinsonism that occurs during drug exposure and resolves within six months after the withdrawal of the implicated agent [12], even though symptoms can persist beyond six to nine months cessation of the drug without evidence of impaired striatal dopamine transporter density [18]. Drug-induced parkinsonism may be distinguished from Parkinson's disease, since contrary to the latter, drug-induced parkinsonism is characterized by bilateral and symmetric parkinsonism, with more prominent bradykinesia and rigidity. Nonetheless, relying exclusively on the clinical manifestation of parkinsonian symptoms in order to differentiate between druginduced parkinsonism and other causes is not a reliable and feasible strategy particularly in seniors who commonly develop atypical symptom phenotypes [12]. Indeed, more than $30 \%$ of patients with drug-induced parkinsonism show asymmetric parkinsonism and tremor at rest $[12,38]$.

In older adults treated with antipsychotics, the puzzle of the genesis and clinical manifestation of parkinsonian symptoms are further perplexed by the heavy burden of coexisting brain pathologies (e.g. amyloidosis, cerebrovascular alterations, mitochondrial abnormalities) [39, 40]. The clinical expression of such brain pathologies may be potentiated or masked by a complex, dynamic interplay between the interacting co-pathologies and harmful and protective environmental factors (e.g. diet and lifestyle parameters, motor reserve) [41, 42]. Exposure to antipsychotic agents influences this interplay and may trigger the development of clinically evident parkinsonian symptoms. This dynamic equilibrium is mirrored in the complex relationships between DaTSCAN- and MRI- findings, clinical diagnoses and 12-month follow-up outcome (resolution vs. persistence of parkinsonian symptoms) in the presented eight cases. For instance, bilateral basal ganglia ischemic lesions seem to have increased the vulnerability of case 8 to the development of parkinsonian symptoms, even though he/she was treated with quetiapine, i.e. an atypical antipsychotic with low risk of aggravation of parkinsonism [12].

Deciphering the cause of parkinsonian symptoms in seniors treated with antipsychotics is crucial for designing the proper, individualized therapeutic plan. Prescribing antiparkinsonian drugs without an established diagnosis of Parkinson's disease or even of a Parkinsonplus syndrome, which albeit responds in most cases poorly to current therapies compared to Parkinson's disease [43], is not justifiable. Antiparkinsonian agents can lead to further exacerbation of psychotic symptoms (dopaminergic agents) or induce cognitive impairment or delirium (anticholinergic agents), whilst polypharmacy is related to adverse outcomes, including adverse drug events and disability in this age group [44, 45]. On the other hand, cessation of the assumed causative agent in order to shed light on the cause of the parkinsonian symptoms and distinguish between drug-induced parkinsonian symptoms and a movement disorder may not be practical in many cases, since depression in late life tends to be a persistent or recurrent and not rarely a therapy resistant condition [23], while persistence or paradoxical progressive deterioration of parkinsonism upon antipsychotic withdrawal have been described [30, 46]. Thus, a rigorous and comprehensive diagnostic workup of parkinsonian symptoms, including structural brain imaging and DaTSCAN, seems to be in cases with atypical, severe and/or persistent parkinsonian symptoms inevitable, in order to design justifiable, individualized treatment plans. In addition, such a diagnostic workup can be prospectively conducted in patients thought to be at high risk for parkinsonism because of age, family history or subthreshold parkinsonian symptoms [30], so that a vulnerable degenerated nigrostriatal tract is identified and considered in decision making about the treatment plan.

Despite the phenotypic homogeneity and the thorough and rigorous diagnostic workup of the considered patients, the presented case series has a number of limitations. Even though all patients suffered from severe depressive symptoms on admission, four were diagnosed at discharge with recurrent depressive disorder and four with organic mood disorder, while in one case the 
diagnosis of bipolar disorder had been established prior hospital admission. Moreover, the age of onset of the first mood disorder episode as well as performance on MMSE varied across the cases. Only four cases can be classified as suffering from late-onset depression. In four cases MMSE scores pointed to clinically significant abnormalities in cognitive function [21]. Taking into account the differences in symptoms and pathogenesis of late-onset depression compared to other forms of depression [23], the complex relationship between depression and cognitive impairment in seniors [47], as well as the higher vulnerability of older adults to side effects of antipsychotics, studies on parkinsonian symptoms with homogenous samples with regard to mental disorder diagnosis, age at symptom onset, cognitive status and antipsychotic medication are needed. In the present cases series, the follow-up assessment was conducted twelve months after hospital discharge, although druginduced parkinsonian symptoms can persist longer than twelve months after cessation of the offending drug [12]. However, in general they resolve in six to nine months and $70 \%$ of patients usually recover within a few months after withdrawal of the causative drug [12, 36]. In addition, the diagnostic tools employed in the eight presented cases are characterized by shortcomings. For instance, the SAS has been criticized for overemphasizing body rigidity [48] and DaTSCAN interrater variability and inconsistencies between visual interpretation and classification based on quantitative radiotracer uptake calculation [49], which were also observed in cases presented here (Table 3), are further sources of uncertainty. Regarding the impact of DaTSCAN, the diagnosis itself is not exclusively driven by imaging findings, although physicians reported previously that DaTSCAN influences their final diagnosis, confidence in their diagnosis and management of the patient [50]. Of note, a case series including eight individuals does not suffice to generalize conclusions. Nonetheless, the observed differences in cause and 12-month follow-up outcome in this limited number of depressed older adults treated with antipsychotics point to the uncertainties related to the pathogenesis and development of parkinsonian symptoms in this clinical phenotype and age group and may fuel future research aiming to shed more light on a diagnostic riddle with therapeutic and prognostic implications.

In conclusion, detecting the cause of parkinsonian symptoms in seniors who are exposed to antipsychotics and subsequently taking appropriate action is a challenging task. Indeed, parkinsonian symptoms cannot be straightforwardly classified as drug-induced in older adults treated with antipsychotics. Age-related neurodegenerative and vascular brain changes may underlie parkinsonism and shape a terrain of unreliable clinical characteristics, ambiguous exam findings and in many cases hardly justifiable therapeutic choices. Comprehensive diagnostic workup is in cases with atypical, severe and/or persistent parkinsonian symptoms the only feasible strategy for developing proper treatment plans. The field of deciphering the cause of parkinsonian symptoms in seniors treated with antipsychotics merits a systematic and thorough study of possible clinical, imaging and outcome endophenotypes of such symptoms, so that in the future personalized and efficient therapeutic strategies can be designed. Familiarizing clinical psychiatrists with effective ways to cope with inconsistent and/or ambiguous imaging and clinical data and make good diagnostic and therapeutic decisions is another step towards this direction.

\section{Abbreviations}

5-HT2A receptor: 5-hydroxy-tryptamin-type 2A receptor; GDS: Geriatric depression scale; MMSE: Mini-mental state examination; SAS: Simpson-Angus scale; MRI: Magnetic resonance imaging; FLAIR: Fluid Attenuation Inversion Recovery; DWI: Diffusion weighted imaging; MTA: Medial temporal lobe atrophy; DaTSCAN: Ioflupane (I-123) dopamine transporter (DAT) single photon emission computerized tomography (SPECT); SBI: specific binding index; ICD-10: International Statistical Classification of Diseases and Related Health Problems version 10

\section{Acknowledgements \\ Not applicable.}

\section{Authors' contributions}

AP and PA designed this study. NK, KS, GL collected this data. AP, MS, PT, CP, $\mathrm{TH}, \mathrm{GL}, \mathrm{PA}$ analyzed data. AP and PA mainly wrote this manuscript. NK, KS, GL, MS, PT, CP, TH helped in writing the manuscript. All authors have read and approved the final manuscript.

Funding

Not applicable.

Availability of data and materials

All data analyzed during this study are included in this published article in tables or text.

\section{Declarations}

\section{Ethics approval and consent to participate}

The study has been approved by the Bioethics Committee of the Medical School of the National and Kapodistrian University of Athens and was conducted in accordance with the 1964 Helsinki declaration and its later amendments. The authors state that the patients have given their written informed consent for participation in the study. They were deemed by the head psychogeriatrician capable of ethically and medically consenting for their participation.

\section{Consent for publication}

Written informed consent for publication of their clinical details and diagnostic workup findings was obtained from patients, who were deemed by the head psychogeriatrician capable of ethically and medically consenting for publication of these data.

\section{Competing interests}

PA is a member of the editorial board of BMC psychiatry. There has been no significant financial support for this work that could have influenced its outcome.

\section{Author details}

${ }^{1}$ Charing Cross Hospital, Department of Neurosurgery, Imperial College London, London, UK. ${ }^{2}$ First Department of Psychiatry, Eginition Hospital; Department of Pharmacology, Medical School, National and Kapodistrian 
University of Athens, Athens, Greece. ${ }^{3}$ Nuclear Medicine Division, Radiology First Department, "Aretaieion" Hospital, Medical School, National and Kapodistrian University of Athens, Athens, Greece. ${ }^{4}$ First Department of Psychiatry, Eginition Hospital, Medical School, National and Kapodistrian University of Athens, Athens, Greece. ${ }^{5}$ Research Unit of Radiology, Second Department of Radiology, National and Kapodistrian University of Athens and Bioiatriki, Athens, Greece. ${ }^{6}$ First Department of Neurology, Eginition Hospital, Medical School, National and Kapodistrian University of Athens, Athens, Greece. ${ }^{7}$ Department of Nuclear Medicine, Metropolitan Hospital, Neo Faliro, Pireas, Greece. ${ }^{8}$ Department of Psychiatry, Patras University Hospital, Faculty of Medicine, School of Health Sciences, University of Patras, 26504 Rion, Patras, Greece. ${ }^{9}$ Department of Psychiatry and Psychotherapy, Klinikum rechts der Isar, Faculty of Medicine, Technical University of Munich, Munich, Germany.

Received: 26 January 2021 Accepted: 20 May 2021

Published online: 03 June 2021

\section{References}

1. Forlani C, Morri M, Ferrari B, Dalmonte E, Menchetti M, de Ronchi D, et al. Prevalence and gender differences in late-life depression: a populationbased study. Am J Geriatr Psychiatry. 2014;22(4):370-80. https://doi.org/10.1 016/j.jagp.2012.08.015

2. Dong M, Zeng L-N, Zhang Q, Ungvari GS, Ng CH, Chiu HFK, et al. Concurrent antipsychotic use in older adults treated with antidepressants in Asia. Psychogeriatrics. 2019;19(4):333-9. https://doi.org/10.1111/psyg.12416 .

3. Fulone I, Lopes LC. Potentially inappropriate prescriptions for elderly people taking antidepressant: comparative tools. BMC Geriatr. 2017;278(1):278. https://doi.org/10.1186/s12877-017-0674-2 .

4. Gutsmiedl K, Krause M, Bighelli I, Schneider-Thoma J, Leucht S. How well do elderly patients with major depressive disorder respond to antidepressants: a systematic review and single-group meta-analysis. BMC Psychiatry. 2020; 20(1):102. https://doi.org/10.1186/s12888-020-02514-2

5. Bennabi D, Charpeaud T, Yrondi A, Genty J-B, Destouches S, Lancrenon S, et al. Clinical guidelines for the management of treatment-resistant depression: French recommendations from experts, the French Association for Biological Psychiatry and Neuropsychopharmacology and the fondation FondaMental. BMC Psychiatry. 2019;19(1):262. https://doi.org/10.1186/s12 888-019-2237-x

6. Caroff SN, Mu F, Ayyagari R, Schilling T, Abler V, Carroll B. Hospital utilization rates following antipsychotic dose reduction in mood disorders: implications for treatment of tardive dyskinesia. BMC Psychiatry. 2020;20(1): 365. https://doi.org/10.1186/s12888-020-02748-0 .

7. MacQueen GM, Frey BN, Ismail Z, Jaworska N, Steiner M, van Lieshout RJ, et al. Canadian Network for Mood and Anxiety Treatments (CANMAT) 2016 Clinical guidelines for the Management of Adults with major depressive disorder: section 6. Special populations: youth, women, and the elderly. Can J Psychiatr. 2016(9):588-603. https://doi.org/10.1177/0706743716659276

8. Kim-Romo DN, Rascati KL, Richards KM, Ford KC, Wilson JP, Beretvas SN. Medication Adherence and Persistence in Patients with Severe Major Depressive Disorder with Psychotic Features: Antidepressant and SecondGeneration Antipsychotic Therapy Versus Antidepressant Monotherapy. J Manag Care Spec Pharm. 2016;22:588-96. https://doi.org/10.18553/jmcp.201 6.22.5.588.

9. Hereta M, Kamińska K, Białoń M, Wąsik A, Lorenc-Koci E, Rogóż Z. Effect of combined treatment with aripiprazole and antidepressants on the MK-801induced deficits in recognition memory in novel recognition test and on the release of monoamines in the rat frontal cortex. Behav Brain Res. 2020; 112769:112769. https://doi.org/10.1016/j.bbr.2020.112769

10. Divac N, Prostran M, Jakovcevski I, Cerovac N. Second-generation antipsychotics and extrapyramidal adverse effects. Biomed Res Int. 2014; 656370:1-6. https://doi.org/10.1155/2014/656370 .

11. Sykes DA, Moore H, Stott L, Holliday N, Javitch JA, Lane JR, et al. Extrapyramidal side effects of antipsychotics are linked to their association kinetics at dopamine D2 receptors. Nat Commun. 2017;763(1):763. https:/ doi.org/10.1038/s41467-017-00716-z .

12. Shin H-W, Chung SJ. Drug-induced parkinsonism. J Clin Neurol. 2012;8(1): 15-21. https://doi.org/10.3988/jcn.2012.8.1.15.

13. Savica R, Grossardt BR, Bower JH, Ahlskog JE, Mielke MM, Rocca WA Incidence and time trends of drug-induced parkinsonism: a 30-year population-based study. Mov Disord. 2017;32(2):227-34. https://doi.org/10.1 002/mds.26839

14. Trenaman SC, Hill-Taylor BJ, Matheson KJ, Gardner DM, Sketris IS. Antipsychotic drug dispensations in older adults, including continuation after a fall-related hospitalization: identifying adherence to screening tool of older Persons' potentially inappropriate prescriptions criteria using the Nova Scotia Seniors' Pharmacare program and Canadian Institute for Health's discharge databases. Curr Ther Res Clin Exp. 2018;89:27-36. https://doi.org/1 0.1016/j.curtheres.2018.08.002

15. Jellinger KA, Korczyn AD. Are dementia with Lewy bodies and Parkinson's disease dementia the same disease? BMC Med. 2018;34(1):34. https://doi. org/10.1186/s12916-018-1016-8 .

16. Mostile G, Nicoletti A, Zappia M. Vascular parkinsonism: still looking for a diagnosis. Front Neurol. 2018;9:411. https://doi.org/10.3389/fneur.2018.00411.

17. Bridel C, Garibotto V. Teaching Neurolmages: drug-induced parkinsonism with asymmetrical putaminal DaT binding. Neurology. 2015;84(20):e159. https://doi.org/10.1212/WNL.0000000000001590

18. Lim TT, Ahmed A, Itin I, Gostkowski M, Rudolph J, Cooper S, et al. Is 6 months of neuroleptic withdrawal sufficient to distinguish drug-induced parkinsonism from Parkinson's disease? Int J Neurosci. 2013;123(3):170-4. https://doi.org/10.3109/00207454.2012.732976

19. Cummings JL, Henchcliffe C, Schaier S, Simuni T, Waxman A, Kemp P. The role of dopaminergic imaging in patients with symptoms of dopaminergic system neurodegeneration. Brain. 2011;134(11):3146-66. https://doi.org/10.1 093/brain/awr177.

20. Kerstens VS, Varrone A. Dopamine transporter imaging in neurodegenerative movement disorders: PET vs. SPECT Clin Transl Imaging. 2020;8(5):349-56. https://doi.org/10.1007/s40336-020-00386-w .

21. Fountoulakis KN, Tsolaki M, Chantzi H, Kazis A. Mini mental state examination (MMSE): a validation study in Greece. Am J Alzheimers Dis Other Dement. 2000;15(6):342-5. https://doi.org/10.1177/153331750001500604

22. Fountoulakis KN, Tsolaki M, lacovides A, Yesavage J, O'Hara R, Kazis A, et al. The validation of the short form of the geriatric depression scale (GDS) in Greece. Aging (Milano). 1999;11(6):367-72. https://doi.org/10.1 007/BF03339814

23. Alexopoulos GS. Mechanisms and treatment of late-life depression. Transl Psychiatry. 2019;9(1):188. https://doi.org/10.1038/s41398-019-0514-6 .

24. World Health Organization. International statistical classification of diseases and related health problems. 10th ed. Geneva: World Health Organization; 2004.

25. Simpson GM, Angus JW. A rating scale for extrapyramidal side effects. Acta Psychiatr Scand Suppl. 1970;212(S212):11-9. https://doi.org/10.1111/j.16000447.1970.tb02066.x

26. Wahlund LO, Barkhof F, Fazekas F, Bronge L, Augustin M, Sjögren M, et al. A new rating scale for age-related white matter changes applicable to MRI and CT. Stroke. 2001;32(6):1318-22. https://doi.org/10.1161/01.str.32.6.1318

27. Oudega ML, Siddiqui A, Wattjes MP, Barkhof F, ten Kate M, Muller M, et al. Are apathy and depressive symptoms related to vascular white matter Hyperintensities in severe late life depression? I Geriatr Psychiatry Neurol. 2021;34(1):21-8. https://doi.org/10.1177/0891988720901783 .

28. Scheltens $P$, Launer $L$, Barkhof F, Weinstein $H C$, van Gool WA. Visual assessment of medial temporal lobe atrophy on magnetic resonance imaging: interobserver reliability. J Neurol. 1995;242(9):557-60. https://doi. org/10.1007/BF00868807.

29. Papageorgiou SG, Karantoni E, Pandis D, Kouzoupis AV, Kalfakis N, Limouris GS. Severe dopaminergic pathways damage in a case of chronic toluene abuse. Clin Neurol Neurosurg. 2009;111(10):864-7. https://doi.org/10.1016/j. clineuro.2009.07.007

30. Politis AM, Kokras N, Pappa D, Siarkos C, Katirtzoglou E, Papadimitriou GN, et al. A severe and irreversible case of tardive rigid-akinetic parkinsonian syndrome: the role of the DaTscan. J Psychiatr Pract. 2013;19(5):413-8. https://doi.org/10.1097/01.pra.0000435041.13921.a8 .

31. Benamer HTS, Patterson J, Grosset DG, Booij J, de Bruin K, van Royen E, et al. Accurate differentiation of parkinsonism and essential tremor using visual assessment of [1231]-FP-CIT SPECT imaging: the [1231]-FP-CIT study group. Mov Disord. 2000;15(3):503-10. https://doi.org/10.1002/1531-8257(2 00005)15:3<503::AID-MDS1013>3.0.CO;2-V .

32. Nakamura S. DAT-scan in diagnosis of idiopathic Parkinson's disease: European congress of radiology; 2017.

33. Thomas AJ, Donaghy P, Roberts G, Colloby SJ, Barnett NA, Petrides G, et al. Diagnostic accuracy of dopaminergic imaging in prodromal dementia with 
Lewy bodies. Psychol Med. 2019;49(3):396-402. https://doi.org/10.1017/ S0033291718000995.

34. Gayed I, Joseph U, Fanous M, Wan D, Schiess M, Ondo W, et al. The impact of DaTscan in the diagnosis of Parkinson disease. Clin Nucl Med. 2015;40(5): 390-3. https://doi.org/10.1097/RLU.0000000000000766 .

35. Foubert-Samier A, Helmer C, Perez F, Le Goff M, Auriacombe S, Elbaz A, et al. Past exposure to neuroleptic drugs and risk of Parkinson disease in an elderly cohort. Neurology. 2012;79(15):1615-21. https://doi.org/10.1212/WNL. 0b013e31826e25ce.

36. Jeong S, Cho H, Kim YJ, Ma H-I, Jang S. Drug-induced parkinsonism: a strong predictor of idiopathic Parkinson's disease. PLoS One. 2021;16(3): e0247354. https://doi.org/10.1371/journal.pone.0247354 .

37. Kim J-S, Oh Y-S, Kim Y-I, Yang D-W, Chung Y-A, You I-R, et al. Combined use of ${ }^{123}$-metaiodobenzylguanidine (MIBG) scintigraphy and dopamine transporter (DAT) positron emission tomography (PET) predicts prognosis in drug-induced parkinsonism (DIP): a 2-year follow-up study. Arch Gerontol Geriatr. 2013;56(1):124-8. https://doi.org/10.1016/..archger.2012.05.001

38. Munhoz RP, Bertucci Filho D, Teive HAG. Not all drug-induced parkinsonism are the same: the effect of drug class on motor phenotype. Neurol Sci. 2017;38(2):319-24. https://doi.org/10.1007/s10072-016-2771-y

39. Park J-S, Davis RL, Sue CM. Mitochondrial dysfunction in Parkinson's disease: new mechanistic insights and therapeutic perspectives. Curr Neurol Neurosci Rep. 2018;18(5):21. https://doi.org/10.1007/s11910-018-0829-3 .

40. Araki K, Yagi N, Aoyama K, Choong C-J, Hayakawa H, Fujimura H, et al, Parkinson's disease is a type of amyloidosis featuring accumulation of amyloid fibrils of a-synuclein. Proc Natl Acad Sci U S A. 2019;116(36):179639. https://doi.org/10.1073/pnas.1906124116

41. Chung SJ, Lee JJ, Lee PH, Sohn YH. Emerging Concepts of Motor Reserve in Parkinson's Disease. J Mov Disord. 2020;13:171-84. https://doi.org/10.14802/ jmd.20029.

42. Seidl SE, Santiago JA, Bilyk H, Potashkin JA. The emerging role of nutrition in Parkinson's disease. Front Aging Neurosci. 2014;6:36. https://doi.org/10.33 89/fnagi.2014.00036

43. Armstrong MJ, McFarland N. Recognizing and treating atypical Parkinson disorders. Handb Clin Neurol. 2019;167:301-20. https://doi.org/10.1016/ B978-0-12-804766-8.00016-9.

44. Wongpakaran N, Wongpakaran $T$, Sirirak $T$, Jenraumjit $R$, Jiraniramai $S$, Lerttrakarnnon P. Predictors of polypharmacy among elderly Thais with depressive and anxiety disorders: findings from the DAS study. BMC Geriatr. 2018;18(1):309. https://doi.org/10.1186/s12877-018-1001-2 .

45. Davies LE, Spiers G, Kingston A, Todd A, Adamson J, Hanratty B. Adverse outcomes of Polypharmacy in older people: systematic review of reviews. J Am Med Dir Assoc. 2020;21 (2):181-7. https://doi.org/10.1016/j.jamda.2019.10. 022 .

46. Florescu A, Whitney D, Bhatti D, Bertoni JM, Torres-Russotto D. Paradoxical worsening of parkinsonism upon neuroleptic withdrawal: more common than we think? Parkinsonism Relat Disord. 2018;52:115-6. https://doi.org/1 0.1016/.jparkreldis.2018.03.018

47. Holmquist S, Nordström A, Nordström P. The association of depression with subsequent dementia diagnosis: a Swedish nationwide cohort study from 1964 to 2016. PLoS Med. 2020;17(1):e1003016. https://doi.org/10.1371/journa l.pmed.1003016

48. Janno S, Holi MM, Tuisku K, Wahlbeck K. Validity of Simpson-Angus scale (SAS) in a naturalistic schizophrenia population. BMC Neurol. 2005;5(1). https://doi.org/10.1186/1471-2377-5-5 .

49. Booij J, Dubroff J, Pryma D, Yu J, Agarwal R, Lakhani P, et al. Diagnostic performance of the visual Reading of 123/-loflupane SPECT images with or without quantification in patients with movement disorders or dementia. Nucl Med. 2017:58(11):1821-6. https://doi.org/10.2967/jnumed.116.189266

50. Seifert KD, Wiener Jl. The impact of DaTscan on the diagnosis and management of movement disorders: a retrospective study. Am J Neurodegener Dis. 2013;2(1):29-34.

\section{Publisher's Note}

Springer Nature remains neutral with regard to jurisdictional claims in published maps and institutional affiliations.

\section{Ready to submit your research? Choose BMC and benefit from:}

- fast, convenient online submission

- thorough peer review by experienced researchers in your field

- rapid publication on acceptance

- support for research data, including large and complex data types

- gold Open Access which fosters wider collaboration and increased citations

- maximum visibility for your research: over $100 \mathrm{M}$ website views per year

At BMC, research is always in progress.

Learn more biomedcentral.com/submissions 